Volume 8

\title{
Hotels in Distress: Surviving an Economic Downturn Through Non- Traditional Contracting
}

Leslie McKee

Texas A\&M University School of Law (Student), lesliemckee@tamu.edu

Follow this and additional works at: https://scholarship.law.tamu.edu/journal-of-property-law

Part of the Commercial Law Commons, and the Property Law and Real Estate Commons

\section{Recommended Citation}

Leslie McKee, Hotels in Distress: Surviving an Economic Downturn Through Non-Traditional Contracting, 8 Tex. A\&M J. Prop. L. 73 (2022).

Available at: https://doi.org/10.37419/JPL.V8.I2.2

This Notes \& Comments is brought to you for free and open access by Texas A\&M Law Scholarship. It has been accepted for inclusion in Texas A\&M Journal of Property Law by an authorized editor of Texas A\&M Law Scholarship. For more information, please contact aretteen@law.tamu.edu. 


\title{
Hotels IN DiSTRESS: SURVIVING AN ECONOMIC DOWNTURN THROUGH NON-TRADITIONAL CONTRACTING
}

\author{
Leslie McKeet \\ Abstract
}

\begin{abstract}
The hospitality industry is no stranger to market fluctuation, but with the onset of a global pandemic, 2020 left its mark as the worst year on record for the industry. With vacancy permeating hotels across the nation, hotel owners faced a year of tough financial decisions, while the unrelenting demands of mortgage payments and operating expenses loomed in the background. Uncertainty became the new normal, and the term "unprecedented" became commonplace as the pandemic lingered beyond initial expectations. The one-year anniversary of the 2019 novel coronavirus ("COVID-19") pandemic passed without effect as the crisis situation spilled over into a new year. Struggling to survive the economic devastation accompanying the pandemic, many hoteliers pursued alternate income sources. However, alternate usage is not an entirely foreign concept in the hotel industry. While the emergency response to COVID-19 has been by far the largest scale the nation has experienced, it is certainly not the first. Hotels across the country have contracted in the past to provide emergency response in disaster situations, such as hurricanes, wildfires, floods, and for non-disaster housing for the homeless. As of the time of publication of this Comment, the pandemic itself has waned, but the economic effects remain. Although no one can truly predict when the pandemic will fully subside and the economy will return to normal, the current situation is surely a temporary one. What can hotel owners learn from the global pandemic, and will this crisis permanently

DOI: https://doi.org/10.37419/JPL.V8.I2.2

$\dagger$ J.D. Candidate, Texas A\&M University School of Law, Spring 2022. I would like to thank Professor Milan Markovic for serving as my faculty advisor and Annie Counts for her assistance as Note and Comment Editor. I would also like to thank Wade Satterwhite for his invaluable mentorship and professional guidance. Finally, I am forever grateful to my family and John Schmidt for their unconditional support and encouragement throughout this writing process and the pursuit of my legal career.
\end{abstract}


change owners' business models? The most resilient of business owners will glean valuable lessons, adapt their approach, and press forward. This Comment highlights key areas of concern with alternate usage and provides practical guidance for hotel owners struggling to survive the pandemic's crippling effect on the economy and implement plans for the future.

I. INTRODUCTION. 74

II. COVID-19 AND THE HOTEL INDUSTRY:

CRISIS DURING PANDEMIC 77

III. THE HOTEL INDUSTRY TURNS TO

ALTERNATIVE INCOME SOURCES

IV. FEDERAL GOVERNMENT CONTRACTING FOR DISASTER RELIEF .. 81

A. Disaster Response During Hurricanes Katrina and Rita 82

B. Disaster Response During COVID-19 83

C. Contracting for the Future: Contract Extensions and Advance Planning Contracts ........................................ 85

V. RiSK MANAGEMENT AND ALTERNATE USAGE ........................... 89

A. Liability Protection ...................................................... 89

B. Commercial Insurance Coverage .................................... 91

C. Contract Negotiations ................................................ 92

1. Indemnification..................................................... 92

2. Changes Clause ....................................................... 93

D. Sovereign Immunity ..................................................... 94

1. Reduced Hotel Property Values............................... 96

2. Community Resistance ............................................ 97

VI. PERMANENT Hotel PROPERTY CONVERSION .............................. 99

A. Selling Hotel Properties: Investor Purchase versus

Government Purchase .............................................. 99

B. Commandeering and Permanent Conversion ................. 100

VII. CONCLUSION........................................................................... 102

\section{INTRODUCTION}

There is no debate that the onset of the COVID-19 pandemic brought the global economy to a sudden halt, and the hospitality industry suffered a severe economic impact. ${ }^{1}$ Industry leaders and hoteliers across the country faced financial devastation and, in many cases,

1. State of the Hotel Industry Analysis: COVID-19 Six Months Later, AM. HOTEL \& LODGING ASS'N, at 2, (Aug. 31, 2020), https://www.ahla.com/sites /default/files/State\%20of\%20the\%20Industry.pdf [http://perma.cc/4DT6-HZWT] [hereinafter Industry Analysis]. 
foreclosure. ${ }^{2}$ This Comment will examine the hospitality industry's response to past disasters, the current state of economic conditions, and forecasted market projections for the future of the hotel industry.

The hospitality industry's economic condition has a broad-reaching impact because hospitality is vital to the overall national economy, providing a large percentage of the national employment and being directly tied to the revenue flow of the surrounding communities. ${ }^{3}$ Many hotel owners turned to alternative property usages to provide income sources in efforts to salvage their businesses and avoid foreclosures. ${ }^{4}$ The search for income-producing, non-traditional hotel usage may involve federal government funding and contract negotiations with various levels of government. ${ }^{5}$

While hoteliers may find themselves eager to negotiate contracts and replenish revenue streams, these transactions require due diligence and the guidance of legal counsel to protect hotel interests throughout the negotiation process. ${ }^{6}$ Owners need to examine all aspects of the proposed non-traditional property usage, including potential repercussions such as community push-back and premises liability claims, along with potentially long-lasting effects on future revenues. ${ }^{7}$ Additionally, prudent risk management strategies should include insurance policy reviews and procurement to mitigate liability exposure and place owners in the best possible position to benefit financially

2. Mary K. Jacob, NYC Faces Crisis of Empty Hotels Amid COVID Pandemic, N.Y. Post (Mar. 9, 2021, 3:44 PM), https://nypost.com/2021/03/09/nyc-faces-crisis -of-empty-hotels-amid-covid-19-pandemic/ [http://perma.cc/Z2U2-CJMH].

3. Industry Analysis, supra note 1, at 8.

4. Will Feuer \& Emma Newburger, Empty Hotels 'Keep the Lights on' by Converting Into Coronavirus Quarantines, Emergency Housing for First Responders, CNBC (Apr. 8, 2020, 7:01 AM), https://www.cnbc.com/2020/04/07/empty-hotelsconvert-into-coronavirus-quarantines-emergency-housing-to-keep-the-lightson.html [http://perma.cc/2FFP-9RTP].

5. Id.

6. COVID-19: Addressing the Risks of Nontraditional Hotel Use, MARSH MCLENNAN, https://www.marsh.com/us/insights/research/covid-19-addressingrisks-of-nontraditional-hotel-use.html [http://perma.cc/UB66-G69Y].

7. See Chris Glorioso, NYC Residents Want Homeless Moved Out of Hotels, Fear Their Safety is Compromised, NBC N.Y. (Aug. 7, 2020, 9:23 AM), https:/ /www.nbcnewyork.com/news/local/nyc-residents-want-homeless-moved-out-ofhotels-fear-their-safety-is-compromised/2556242/ [http://perma.cc/2KXD-KXYK]; see also COVID-19: Addressing the Risks of Nontraditional Hotel Use, MARSH MCLENNAN, https://www.marsh.com/us/insights/research/covid-19-addressingrisks-of-nontraditional-hotel-use.html [http://perma.cc/UB66-G69Y]; ANNE R. LlOYD-JONES ET AL., THE IMPACT OF COVID-19 ON Hotel VAluES 10 (2020), https://www.hvs.com/article/8745-the-impact-of-covid-19-on-hotel-values [http:/ /perma.cc/Q4ER-WLYR]. 
from non-traditional property use. ${ }^{8}$ These concerns are not limited strictly to immediate negotiations but should be considered as current conditions evolve and in future contracts for emergency relief. ${ }^{9}$ Taking cues from past disasters, such as Hurricanes Katrina and Rita, ${ }^{10}$ along with the pandemic disaster, hotel owners should consider negotiating advanced planning emergency-based contracts in order to provide quick response and minimal income disruption in future circumstances.

Ultimately, a number of hotels may not be able to withstand the financial hardships of the COVID-19 pandemic and the lingering economic downturn. ${ }^{11}$ For hotel properties struggling to sustain business operations, liquidation may be the most viable option. ${ }^{12}$ The pandemic brought national attention to the existing urban homelessness crisis, and advocates pushed for conversion of hotel properties into permanent housing facilities. ${ }^{13}$ Property owners need to be aware of opportunities for potential property sales during this unique time, be equally cognizant of the threat of commandeering, and weigh their decisions carefully. ${ }^{14}$

Part II of this Comment provides an overview of the current state of the hotel industry, touching on the economic devastation brought about by the pandemic. Market projections forecast a long-lasting effect on the financial state of the industry as travel struggles to gain

8. COVID-19: Addressing the Risks of Nontraditional Hotel Use, MARSH MCLENNAN, https://www.marsh.com/us/insights/research/covid-19-addressingrisks-of-nontraditional-hotel-use.html [http://perma.cc/UB66-G69Y].

9. Id.

10. U.S. Gov't Accountability OfF., GAO-07-88, Disaster Assistance: Better Planning Needed for Housing Victims of Catastrophic Disasters, at 1 (2007), https://www.gao.gov/assets/260/257122.pdf [http://perma.cc/B9AG6NQ9] [hereinafter GAO-07-88].

11. See Mary K. Jacob, NYC Faces Crisis of Empty Hotels Amid COVID Pandemic, N.Y. Post (Mar. 9, 2021, 3:44 PM), https://nypost.com/2021/03/09/nycfaces-crisis-of-empty-hotels-amid-covid-19-pandemic/ [http://perma.cc/Z2U2CJMH].

12. Id.

13. Jake Blumgart, Why US Cities Haven't Just Given Every Person a Hotel Room During the Pandemic, CITY Monitor (Apr. 28, 2020, last updated Mar. 1, 2021), https://citymonitor.ai/environment/why-us-cities-havent-just-given-everyhomeless-person-a-hotel-room-during-the-pandemic [http://perma.cc/BL6UTK6Z].

14. Ananya Roy et al., Hotel California: Housing the Crisis, UCLA LUSKIN INST. ON INEQ. \& DEMOCRACY, at 22, (July 9, 2020), https://escholarship.org/content /qt0k8932p6/qt0k8932p6_noSplash

5619d4b10747c86e7ad8e46197b6fd44.pdf?t=qd7a4r [http://perma.cc/NQ8N$\overline{\mathrm{E}} 3 \mathrm{GK}]$. 
traction both nationally and globally. ${ }^{15}$ In Part III, this Comment presents examples of several forms of alternate usages of hotel properties when owners made initial attempts to lessen the financial hardship during lockdowns and travel bans. Part IV examines the role of the federal government in the overall disaster and emergency relief response framework. Funding and procedures evolved in light of past emergency response weaknesses, providing the foundation for many alternate usages. ${ }^{16}$ Likewise, the pandemic disaster response could potentially open the door to increased hotel contracting opportunities.

In Part V, this Comment highlights the potential issues associated with alternate usage of hotel properties. There are many areas of concern for owners to address when attempting to negotiate contracts. ${ }^{17}$ Risk mitigation during pandemic response is largely concentrated on issues directly related to infectious disease, ${ }^{18}$ however, risk mitigation strategies can apply to a broader application of future alternate usages. Finally, Part VI briefly addresses permanent conversion of hotel properties. While some hotel owners may seek permanent conversion as a viable option, there are properties facing a push for commandeering to convert to permanent alternate housing. ${ }^{19}$ Although not likely to be a common occurrence, owners should be aware that the potential for commandeering exists and understand how the legal framework of their specific locale addresses this process.

\section{COVID-19 AND THE HOTEL INDUSTRY: CRISIS DURING PANDEMIC}

When COVID-19 brought the world to its knees in 2020, the economy struggled to cope with the effects of an unprecedented global pandemic. ${ }^{20}$ As shelter-in-place orders began to sweep the nation and halt the economy, industries across the United States suffered. ${ }^{21}$ Businesses closed and travel ceased, which made the hotel industry one of

15. See State of the Hotel Industry 2021, AM. Hotel \& LODGING Ass'N, at 3, (Jan. 21, 2021), https://www.ahla.com/sites/default/files/2021_state_of the_industry_0.pdf [http://perma.cc/6XUY-SKZE] [hereinafter Hotel In $\bar{d} u s t r y-20 \overline{2} 1]$.

16. GAO-07-88, supra note 10 , at 1 .

17. COVID-19: Addressing the Risks of Nontraditional Hotel Use, MARSH MCLENNAN, https://www.marsh.com/us/insights/research/covid-19-addressingrisks-of-nontraditional-hotel-use.html [http://perma.cc/UB66-G69Y].

18. See id.

19. Roy et al., supra note 14, at 22.

20. See Industry Analysis, supra note 1, at 2, 8; see also COVID-19: Addressing the Risks of Nontraditional Hotel Use, MARSH MCLENNAN, https://www.marsh.com /us/insights/research/covid-19-addressing-risks-of-nontraditional-hotel-use.html [http://perma.cc/UB66-G69Y].

21. Industry Analysis, supra note 1, at 2. 
the first severely affected industries. ${ }^{22}$ One of the first affected and likely one of the last to recover, American Housing and Lodging Association ("AHLA") asserted that the hotel industry was on the brink of collapse. ${ }^{23}$ Industry research claimed that the impact "on the travel industry has been nine times worse than September 11," and projected 2020 to be the "worst year on record for hotel occupancy." 24

AHLA's 2020 State of the Hotel Industry report focused primarily on the record-low occupancy rates and the bleak travel forecast as the most critical issues facing the hotel industry. ${ }^{25}$ As the pervasive pandemic conditions continued into a new calendar year, the industry outlook showed little improvement. ${ }^{26}$ The AHLA's newly published 2021 report, State of the Hotel Industry, reiterated the devastating effects of low occupancy on the survival of the hotels. ${ }^{27}$ At the peak of the pandemic, occupancy rates were at an all-time low of only $24.5 \% .{ }^{28} \mathrm{Grad}-$ uated stages of reopening did have a slightly positive effect on occupancy rates; however, the upward trend met resistance at the end of 2020 with a resurgence of virus cases and an unsteady process for vaccine roll-out. ${ }^{29}$ Occupancy rates have been projected to hold close to $50 \%$ for the remainder of 2021, which is a critical occupancy threshold for the survival of hotels. ${ }^{30}$ Operating at half capacity is generally the break-even point for most in the accommodations business. ${ }^{31}$ This ratio will typically just cover operating expenses-with no allowances for debt payments or profit margin. ${ }^{32}$

One of the biggest hurdles hotels face is the projected long-term effects on the travel industry. ${ }^{33}$ AHLA predicted that travel would slowly return in three graduated phases-leisure travel, followed by small to medium-sized event bookings, with business travel being the slowest to return. ${ }^{34}$ Following those predictions, when families began

22. $I d$.

23. $I d$.

24. Hotel Industry on Brink of Collapse Releases Roadmap to Recovery, AM. HoTEL \& LODGING ASs'N, (May 20, 2020), https://www.ahla.com/press-release/hotel-industry-brink-collapse-releases-roadmap-recovery [http://perma.cc/26WZAXL4].

25. See Industry Analysis, supra note 1.

26. See Hotel Industry 2021, supra note 15, at 4.

27. See id.

28. Id. at 6 .

29. Id. at 3 .

30. Id. at 6 .

31. Id.

32. Id.

33. Id. at 4.

34. Id. at 9 . 
to resume leisure travel in a very limited scope towards the end of 2020, the same did not hold true for business travel—which typically provides the largest portion of overall hotel revenue. ${ }^{35}$ Hotels in urban markets, often located near airports or convention centers, rely heavily on bookings related to conferences, meetings, and standard business travel. ${ }^{36}$ Even as nationwide occupancy rates began to slightly increase towards the end of 2020, the occupancy rates in urban areas continued to lag because businesses across the country had adapted to shelter-inplace orders and transitioned to remote alternatives in an effort to maintain operations. ${ }^{37}$

Possibly the most concerning of the predictions related to longterm pandemic impact is the grim outlook for business travel to return to normal. ${ }^{38}$ The harsh reality is that the pandemic may very well have a lasting effect on business travel with remote meetings and teleconferencing becoming the new normal. ${ }^{39}$ The North American companies participating in the AHLA research study collectively stated that they had replaced all non-essential travel with technological alternatives, such as videoconferencing. ${ }^{40}$ The return to business travel could vary by industry, but the research points to the likelihood that certain aspects of the traditional pre-COVID business travel model may never return. ${ }^{41}$ Hotels that are dependent on business travel, meetings, and conferences face the reality that it could take until 2024 or even later to regain occupancy rates comparable to those prior to the pandemic. ${ }^{42}$ For struggling hotels to survive another two to three years at breakeven capacity, alternate sources of income may be the critical key to bridging the financial gap.

\section{ThE Hotel InDUSTRY TURnS TO ALternAtIVE InCOME SOURCES}

At the onset of the pandemic, industry leaders began looking for funding and alternative sources of income to sustain struggling

35. $I d$.

36. Industry Analysis, supra note 1, at 7.

37. Hospitality and COVID-19: How Long Until 'No Vacancy' for US Hotels?, MCKINSEY \& CO. (June 10, 2020), https://www.mckinsey.com/industries/travel-logistics-and-transport-infrastructure/our-insights/hospitality-and-covid-19-how-long -until-no-vacancy-for-us-hotels [http://perma.cc/AP4D-MYEM].

38. $I d$.

39. See id.

40. Id.

41. Id.

42. Hotel Industry 2021, supra note 15, at 9. 
hotels. ${ }^{43}$ In March of 2020, leaders from the U.S. Travel Association, the AHLA, and select hotel executives met with President Donald Trump to discuss possible federal aid and alternative solutions. ${ }^{44}$ The group collectively presented market projections that predicted "decreased travel due to coronavirus could wipe out $\$ 355$ billion in total travel spending, including transportation, lodging, retail, attractions and restaurants." 45 Discussions included government partnerships that would assist in public safety measures while providing some muchneeded financial relief to the industry. ${ }^{46}$ Pleading for federal assistance, the Chief Executive Officer of the AHLA said "[t]he impact to our industry is already more severe than anything we've seen before, including September 11 and the great recession of 2008 combined." 47

Although industry leaders were asking for federal financial assistance, many hotel owners had already begun to pursue alternate sources of income through non-traditional hotel usages. ${ }^{48}$ Hotels in larger American cities have (1) contracted to house frontline medical and emergency personnel, (2) operated as alternate health care facilities for (asymptomatic) COVID-19 positive individuals without symptoms, and (3) provided temporary housing facilities for the homeless. ${ }^{49}$ As the pandemic continued far beyond the initially projected timeframe, select hotels began to contract with universities for

43. Back From the Brink of Collapse: A Roadmap for Recovery for the Hotel Industry, AM. HOTEL \& LODGING ASS'N, https://www.ahla.com/sites/default/files /hotel_industry_recovery_roadmap_for_congress_5.20.20_0.pdf [https://perma.cc /LJ5X-R7BB].

44. Lauren Hirsch, Travel Industry Pushes for $\$ 150$ Billion in Aid as Coronavirus Cripples Businesses, CNBC (Mar. 17, 2020, 5:37 PM), https://www.cnbc.com /2020/03/17/travel-industry-pushes-for-150-billion-in-aid-as-coronavirus-cripplesbusiness.html [http://perma.cc/LTX5-X8LM].

45. Id.

46. $I d$.

47. $I d$.

48. Id.; Press Release, City of Chicago: Office of the Mayor, Mayor Lightfoot Announces Large Scale Efforts to Develop a System Caring for All of the City's Residents During Covid-19, (Mar. 23, 2020), https://www.chicago.gov/content/dam /city/depts/mayor/Press\%20Room/Press\%20Releases/2020/March/HotelOperatorPartnership.pdf [http://perma.cc/SMP9-GEYB].

49. Press Release, City of Chicago: Office of the Mayor, Mayor Lightfoot Announces Large Scale Efforts to Develop a System Caring for All of the City's Residents During Covid-19, (Mar. 23, 2020), https:/www.chicago.gov/content/dam/city /depts/mayor/Press\%20Room/Press\%20Releases/2020/March/HotelOperatorPartnership.pdf [http://perma.cc/SMP9-GEYB]; Governor Newsom Announces New Program to Provide Front-Line Workers with Hotel Rooms, CA.GOV (Apr. 9, 2020), https://www.gov.ca.gov/2020/04/09/governor-newsom-announces-new-program-to -provide-front-line-health-care-workers-with-hotel-rooms/ [http://perma.cc/272ZEGVJ]. 
socially-distanced dorm accommodations, with many of those contracts leading to possible permanent conversion. ${ }^{50}$ Additionally, some properties in urban locations negotiated sales contracts to convert hotels to permanent homeless housing. ${ }^{51}$ Many of these alternate usages relied on a pre-existing system of federal funding and involved private parties negotiating and entering into contracts with government entities. $^{52}$

\section{FEDERAL GOVERNMENT CONTRACTING FOR DISASTER RELIEF}

The federal government has an established framework for disaster response to provide emergency shelter and temporary housing in disaster situations. ${ }^{53}$ The Robert T. Stafford Disaster Relief and Emergency Assistance Act ("Stafford Act") of 1988 established programs designed "to provide an orderly and continuing means of assistance by the Federal Government to State and local governments in carrying out their responsibilities to alleviate the suffering and damage which result from such disasters . ..."54 Funds authorized through the Stafford Act provide reimbursement to lower levels of government charged with local-level response during emergency situations and declared disasters. ${ }^{55}$ The Act provides access to federal funding upon the president's declaration of emergency or major disaster conditions. ${ }^{56}$ Additionally, the Homeland Security Act of 2002 addressed efforts to streamline the response of multiple agencies to disaster situations and "develop a comprehensive national plan," which prompted the

50. See Fred DeMicco \& Jackie Guzman, Hotels to Dorms: Converting Hotels to College Housing During the COVID-19 Pandemic, Hosp. NET (Aug. 21, 2020), https://www.hospitalitynet.org/opinion/4100255.html [http://perma.cc/R2WP$5 \mathrm{X} 4 \mathrm{~J}]$.

51. San Diego Announces Proposed Purchase of Two Hotels to Provide Over 330 Units for San Diegans Experiencing Homelessness, SAN DiEGo Hous. Comm'N (Sept. 15, 2020), https://www.sdhc.org/news-release/proposed-purchase-of-hotelsfor-homelessness/ [http://perma.cc/HX8H-8SFX].

52. Coronavirus: Here's How Putting California's Homeless in Hotels Actually Works, MERCURY News (Apr. 11, 2020, 1:42 PM, last updated Sept. 20, 2020, 4:14 PM), https://www.mercurynews.com/2020/04/11/coronavirus-heres-how-puttingcalifornias-homeless-in-hotels-actually-works/ [http://perma.cc/CSZ6-QLMH].

53. See Elizabeth M. Webster et Al., ConG. Rsch. Serv. R46326, StafFord ACt DeClaRATIONS FOR COVID-19 FAQ 19 (2020).

54. 42 U.S.C. $\S 5121$.

55. Stafford Act and COVID-19 Reimbursement Fact Sheet, TenN. State Gov'T (June 9, 2020), https://www.tn.gov/content/dam/tn/education/health-\&-safety/Stafford $\% 20$ Act $\% 20$ and $\% 20$ COVID_19\%20Reimbursement $\% 20$ Fact $\% 20$ Sheet.pdf

[http://perma.cc/H6FK-EK8J].

56. 42 U.S.C. $\S \S 5170,5191$. 
Department of Homeland Services to issue the National Response Plan ("NRP") in 2004. ${ }^{57}$ The intention of the NRP was to "establish a comprehensive, national, all-hazards approach to domestic incident management across a spectrum of activities including prevention, preparedness, response, and recovery," 58 "integrat[ing] the efforts and resources of Federal, State, local, tribal, private-sector, and nongovernmental organizations." ${ }^{59}$ The NRP was put to the test during Hurricane Katrina, which exposed weaknesses in the plan and prompted revisions for a more functional and cohesive disaster response framework. ${ }^{60}$

\section{A. Disaster Response During Hurricanes Katrina and Rita}

When hurricanes Katrina and Rita battered the Gulf Coast region in 2005, the back-to-back disasters left more than a million people displaced from their homes and in need of temporary housing. ${ }^{61}$ Hurricane Katrina exposed problems with NRP implementation-most detrimental being the "lack of preexisting operational plans detailing how the support agencies would provide disaster housing assistance." 62 Studies conducted after the 2005 hurricane season explored the weaknesses in the federal government's disaster response, determining that the overall network of available agencies failed to clearly identify each agency's capabilities and responsibilities. ${ }^{63}$ Congress enacted the Post-Katrina Management Reform Act of 2006 to further integrate response efforts, part of which included revision of the NRP with a successor plan known as the National Response Framework ("NRF") that was implemented in $2008 .{ }^{64}$ The goal was to establish better coordination between the agencies and local governments and to provide more efficient disaster-housing response to victims. ${ }^{65}$ The objective was to (1) provide more streamlined access to federal funding and

57. Homeland Security Act of 2002, Pub. L. No. 107-296, § 201(d)(5), 116 Stat. $2135,2146$.

58. U.S. Dep'T of Homeland Sec., National Response Plan, at 2 (2004), https://www.hsdl.org/?view\&did=450766 [http://perma.cc/K3W3-JZ45].

59. Id. at xi.

60. See Bruce R. Lindsay, Cong. Rsch. Serv., RL34758, The National RESPONSE FramewORK: OVERVIEW AND POSSIBLE ISSUES FOR CONGRESS, CRS-3 (2008), https://fas.org/sgp/crs/homesec/RL34758.pdf [http://perma.cc/Q7EUSFJV].

61. GAO-07-88, supra note 10 , at 1.

62. Id. at 7 .

63. Id. at 5 .

64. LINDSAY, supra note 60 , at CRS-2.

65. Id. at CRS-2, CRS-17; GAO-07-88, supra note 10, at 10. 
local government reimbursement, (2) push for pre-disaster contracting for disaster response, and (3) "implement[] and coordinate[] an accelerated, proactive national response to a catastrophic incident." 66 The post-Katrina focus shifted to contracting, specifically pre-planning contract placement, with a significant increase in government contracting officers and the requirement to secure advance contractsopening the door to increased contracting opportunities for hotels. ${ }^{67}$

\section{B. Disaster Response During COVID-19}

When the COVID-19 pandemic reached national disaster status, Chicago was among the first American cities to announce hotel accommodation contracts. ${ }^{68}$ The initial focus was to provide housing for individuals who had tested positive for the virus without exhibiting symptoms that required hospitalization. ${ }^{69}$ Mayor Lori Lightfoot announced the contracts in March 2020 after collaborating with Chicago-area hotel owners. ${ }^{70}$ In efforts to help prevent the spread of the virus, city officials opted to use vacant hotel space to provide quarantine accommodations rather than to risk these individuals returning home to expose other family members. ${ }^{71}$ The contracts initially provided availability of only 200 rooms, but quickly expanded to include 1,000 rooms throughout the city. ${ }^{72}$ Although public safety concerns during the pandemic were top priority, the city was well aware of the halt in travel, the resulting vacancies, and the economic impact on the area hotels, so it presented these contracts as beneficial to hotel owners suffering from reduced capacity. ${ }^{73}$ Chicago's initial emergency relief housing contracts amounted to roughly $\$ 2$ million per month for hotel occupancy. ${ }^{74}$

66. GAO-07-88, supra note 10 , at 10.

67. U.S. GOV'T ACCOUNTABILITY OfF., GAO-15-783, DisASTER Contracting: FEMA NeEds to COHESIVEly Manage ITS Workforce AND FULLY ADDRESS POST-KATRINA REFORMS, at 13, 26 (2015), https://www.gao.gov /assets/680/672771.pdf [http://perma.cc/LE6X-HKXE] [hereinafter GAO-15-783].

68. Press Release, City of Chicago: Office of the Mayor, Mayor Lightfoot Announces Large Scale Efforts to Develop a System Caring for All of the City's Residents During Covid-19, (Mar. 23, 2020), https://www.chicago.gov/content/dam/city /depts/mayor/Press\%20Room/Press\%20Releases/2020/March/HotelOperatorPartnership.pdf [http://perma.cc/SMP9-GEYB].

69. Id.

70. $I d$.

71. Id.

72. Id.

73. $I d$.

74. Will Feuer \& Emma Newburger, Empty Hotels "Keep the Lights On" by Converting into Coronavirus Quarantines, Emergency Housing for First 
California similarly began to implement housing programs that focused on overflow accommodations for virus patients and medical personnel and provided safe quarantine accommodations for the homeless population. ${ }^{75}$ California Governor Gavin Newsome announced in March 2020 that \$150 million had been authorized for emergency funding, specifically appointed to protect California's homeless population from the spread of COVID-19. ${ }^{76}$ Of that total, $\$ 50$ million was earmarked for purchasing temporary housing trailers and contracting to secure hotel rooms. ${ }^{77}$ The state identified 950 potential hotel properties and had begun to systematically reach out to owners to gauge willingness to participate in the lease negotiations. ${ }^{78}$ Within weeks, Governor Newsome announced a similar program for housing front-line healthcare workers. ${ }^{79}$ The program relied on 150 hotels that committed to provide accommodations at discounted rates, located in high-population areas, and areas that were experiencing high numbers of COVID cases. ${ }^{80}$ The Federal Emergency Management Agency ("FEMA"), available to state and local governments, provided the disaster relief reimbursement funding for these programs. $^{81}$

Numerous programs began to follow, allowing additional opportunities for hotel contracting. In July 2020, California also announced

Responders, CNBC (Apr. 8, 2020, 7:01 AM), https://www.cnbc.com/2020/04/07 /empty-hotels-convert-into-coronavirus-quarantines-emergency-housing-to-keepthe-lights-on.html [http://perma.cc/2FFP-9RTP].

75. Governor Newsom Announces New Program to Provide Front-Line Workers with Hotel Rooms, CA.gOV (Apr. 9, 2020), https://www.gov.ca.gov/2020/04/09 /governor-newsom-announces-new-program-to-provide-front-line-health-careworkers-with-hotel-rooms/ [http://perma.cc/272Z-EGVJ]; Governor Newsom Takes Emergency Actions \& Authorizes \$150 Million in Funding to Protect Homeless Californians from COVID-19, CA.GOV (Mar. 18, 2020), https://www.gov.ca.gov/2020 /03/18/governor-newsom-takes-emergency-actions-authorizes-150-million-infunding-to-protect-homeless-californians-from-covid-19/ [http://perma.cc/R6DMY4UG].

76. Governor Newsom Takes Emergency Actions \& Authorizes $\$ 150$ Million in Funding to Protect Homeless Californians from COVID-19, CA.GOV (Mar. 18, 2020), https://www.gov.ca.gov/2020/03/18/governor-newsom-takes-emergencyactions-authorizes-150-million-in-funding-to-protect-homeless-californians-fromcovid-19/ [http://perma.cc/R6DM-Y4UG].

77. Id.

78. $I d$.

79. Governor Newsom Announces New Program to Provide Front-Line Workers with Hotel Rooms, CA.gOV (Apr. 9, 2020), https://www.gov.ca.gov/2020/04/09 /governor-newsom-announces-new-program-to-provide-front-line-health-careworkers-with-hotel-rooms/ [http://perma.cc/272Z-EGVJ].

80. Id.

81. Id. 
the Housing for the Harvest program, a statewide program to support agricultural and food-processing employees. ${ }^{82}$ California appointed its Department of General Services to "execute the hotel sourcing contracts and utilize travel agency vendors to reserve rooms for eligible participants, similar to the model established in the Hotels for Healthcare Workers Program." 83

\section{Contracting for the Future: Contract Extensions and Advance Planning Contracts}

Criticism of the Katrina response centered around the fact that the magnitude of the disaster exceeded the established disaster response framework and the ability to provide shelter and supplies. ${ }^{84}$ PostKatrina reform focused on pre-planning and the placement of advance contracts to supply a multitude of disaster needs, with temporary housing being a central focus. ${ }^{85}$ Past disaster response efforts concentrated primarily on just the affected region and continued only for a temporary period of time during clean-up and rebuilding, such as in a hurricane zone or wildfire area. ${ }^{86}$

State and local governments initiated positive changes in disaster response planning because Katrina's magnitude surpassed the existing response framework. ${ }^{87}$ In a similar manner, the COVID-19 pandemic surpassed historical national disaster scenarios, crossed regional boundaries to extend nationwide, and continued for well over a year. ${ }^{88}$ The enormity of the pandemic disaster far exceeded the scope of emergency response preparedness for the federal government as well as at local and state levels. ${ }^{89}$ The expanse of the pandemic response should generate ideas for future alternate usage that could supplement income through prearranged contracts. What lessons can this disaster offer to implement a better future response?

82. Housing for the Harvest - Program Overview, CAL. DEP'T OF FOOD AND AGRIC. (July 29, 2020), https://files.covid19.ca.gov/pdf/Housing_for the_HarvestProgram Overview.pdf [http://perma.cc/UC7E-VKP5].

83. $I \bar{d}$.

84. GAO-07-88, supra note 10 , at 6.

85. GAO-15-783, supra note 67, at 31 .

86. LINDSAY, supra note 60, at CRS-2.

87. GAO-07-88, supra note 10, at 1 .

88. WEBSTER ET AL., supra note 53, at 4-5.

89. See FEMA's Natural Disaster Preparedness and Response Efforts During the Coronavirus Pandemic, FEMA (July 24, 2020), https://www.fema.gov/factsheet/femas-natural-disaster-preparedness-and-response-efforts-during-coronavirus -pandemic [http://perma.cc/N64N-EJS7]. 
For federal emergency funding to be available under the Stafford Act to pay for housing, the scenario must be of a large enough magnitude to trigger a declared state of emergency. ${ }^{90}$ This Comment is not suggesting that global pandemics would become a typical pre-planned disaster. However, the pandemic disaster should broaden the scope of potential use of advance contracts for temporary housing. Hotel owners and government contracting officials alike should apply lessons learned during the pandemic, where creative alternate usages bridged financial gaps, ${ }^{91}$ and seek new situations to implement emergencyresponse-temporary housing.

The pandemic-driven economic crisis emphasized the potential of hotel usage beyond the scope of traditional disaster response scenarios. ${ }^{92}$ Proactive owners could consider a broad range of possibilities in which they negotiate the use of their property to provide temporary housing outside of the typical hurricane or flood relocation or housing for emergency personnel fighting wildfires. ${ }^{93}$ Although preparing for future disaster response would not address current income shortcomings, it could be a first step towards actively planning for future alternative usage. Hotel properties can indicate their willingness to negotiate in federal contracts by registering with the Disaster Response Registry $^{94}$ online through the System for Award Management ("SAM") - the gateway to federal procurement opportunities. ${ }^{95}$ SAM

90. WEBSTER ET AL., supra note 53, at 19.

91. See Press Release, City of Chicago: Office of the Mayor, Mayor Lightfoot Announces Large Scale Efforts to Develop a System Caring for All of the City's Residents During Covid-19, (Mar. 23, 2020), https://www.chicago.gov/content/dam /city/depts/mayor/Press\%20Room/Press\%20Releases/2020/March/HotelOperatorPartnership.pdf [http://perma.cc/SMP9-GEYB]; see also Will Feuer \& Emma Newburger, Empty Hotels "Keep the Lights On" by Converting into Coronavirus Quarantines, Emergency Housing for First Responders, CNBC (Apr. 8, 2020, 7:01 AM), https:/www.cnbc.com/2020/04/07/empty-hotels-convert-into-coronavirusquarantines-emergency-housing-to-keep-the-lights-on.html [http://perma.cc/2FFP9RTP].

92. COVID-19: Addressing the Risks of Nontraditional Hotel Use, MARSH MCLENNAN, https://www.marsh.com/us/insights/research/covid-19-addressingrisks-of-nontraditional-hotel-use.html [http://perma.cc/UB66-G69Y].

93. See Roger Stewart, The Risk Associated with Non-Traditional Hotel Use, INS. OFF. OF AM. (Jan. 25, 2021), https:/www.ioausa.us/the-risk-associated-withnon-traditional-hotel-use/ [https://perma.cc/5AFJ-3B5E]; see also COVID-19: Addressing the Risks of Nontraditional Hotel Use, MARSH MCLENNAN, https:/ /www.marsh.com/us/insights/research/covid-19-addressing-risks-of-nontraditionalhotel-use.html [http://perma.cc/UB66-G69Y].

94. See Disaster Response Registry, ACQUISITION, https://www.acquisition.gov /disaster-response-registry [http://perma.cc/6RXF-AJFJ] (providing contractor registration services for the Disaster Response Registry).

95. See id. 
creates a central system for the collection of information about businesses from various industries interested in contracting to provide services after a declared disaster. ${ }^{96}$ Once registered and activated through SAM, the business is added to the Disaster Response Registry, which compiles contractor information to serve as the primary resource for government contracting agents to locate vendors and services in a response scenario. ${ }^{97}$

State and local governments alike could learn from the COVID19 disaster response and consider advance contracts that could benefit citizens in a multitude of situations. By having advance contracts in place, it could reduce the length of time between a designated trigger scenario and the activation of a contingency plan, and minimize the effects of lagging traditional income. ${ }^{98}$ Considering the bleak travel industry projections for the next few seasons, ${ }^{99}$ hotel owners will need to be creative in their business plan and actively seek alternate sources to supplement income. Hotels could provide temporary housing on a contract basis for large-scale construction projects, as temporary operational headquarters, or as university overflow for housing or meeting space-all potential situations which could supplement fluctuating traditional travel income with steady contract-based income. ${ }^{100}$ The benefit of exploring non-disaster contracting options also lies in the fact that these scenarios exist outside the scope of federal funding and would not be limited to a federally declared state of emergency to trigger funding. ${ }^{101}$

Properties that have successfully negotiated government contracts during the pandemic must be cautious of the temporary nature of these contracts ${ }^{102}$ and give serious consideration to the transition process that will follow. National emergency declarations are temporary by design and under normal circumstances terminate

96. Id.

97. Id.

98. Jillian L. Morrison, Post-Disaster Contracting: An Examination of the Costs Associated With the Stafford Act's Local Contracting Preference and Implementation Proposals to Maximize Community Revitalization, 37 PUB. CONT. L.J. 687, 712 (2008).

99. See Hotel Industry 2021, supra note 15, at 5.

100. C.J. Hughes, Pummeled by the Pandemic, Hotel Owners Get Creative With Their Space, N.Y. TIMES (Oct. 6, 2020), https://www.nytimes.com/2020/10/06/business/hotels-transformation-offices-shelters-coronavirus.html [https://perma.cc /Z42F-7PST].

101. Roy et al., supra note 14, at 20 (discussing non-emergency hotel contracting in Los Angeles).

102. 50 U.S.C. $\S 1622(d)$. 
automatically on the declaration anniversary, but the President may extend them through published notice. ${ }^{103}$ President Trump declared a state of national emergency on March 1, 2020, and to prevent statutory automatic termination, President Biden chose to extend the emergency declaration by presidential notice on February 24, 2021. ${ }^{104}$ This extension allowed continued federal funding as the pandemic crisis lingered past the anniversary date. ${ }^{105}$ Contracts for housing frontline workers or homeless populations were beneficial in allowing struggling hotel owners to secure alternate sources of business income, but emergency declarations are temporary and FEMA disaster funding is limited. ${ }^{106}$ As the pandemic subsides and disaster funding ends, local and state governments must transition homeless populations housed by temporary hotel contracts to alternate housing options to allow the hotels to return to normal operations. ${ }^{107}$ When that occurs, hotel owners could find themselves in the position to negotiate with local or state level governments to continue the housing agreements or permanent sale. ${ }^{108}$ Proactive owners interested in continued contract-based income might choose to negotiate continued occupancy agreements, taking advantage of state and local governments faced with forcibly relocating homeless individuals back to the streets. ${ }^{109}$ Considering the potential public backlash from a choice such as this, government leaders are likely open to the prospect of negotiating continued contracts.

103. Id.

104. Continuation of the National Emergency Concerning the Coronavirus Disease 2019 (COVID-19) Pandemic, 86 Fed. Reg. 11,599 (Feb. 26, 2021).

105. 50 U.S.C. $\S 1622(d)$.

106. WEBSTER ET AL., supra note 53, at 5.

107. New York City Begins Moving Homeless Out of Lucerne and Other Hotels as Pandemic Outlook Brightens, CBS N.Y. (June 28, 2021, 5:54 PM), https:/ /newyork.cbslocal.com/2021/06/28/nyc-homeless-out-of-hotels/ [http://perma.cc /6BSW-2LEE].

108. Scott Rodd, California Leasing Hotels for Homeless People During Coronavirus Crisis-and After Could Make Them Permanent Housing, CAPRADIO (Mar. 24, 2020), https://www.capradio.org/articles/2020/03/24/california-leasing-hotelsfor-homeless-people-during-coronavirus-crisis-and-after-could-make-them-permanent-housing/ [http://perma.cc/HF2X-MVCX].

109. Shant Shahrigian, NYC Mayor de Blasio Slammed for Plan to Move Homeless Out of Upper West Side Hotel, DAILY NEWs (Sep. 09, 2020, 5:07 PM), https:/ /www.nydailynews.com/news/politics/ny-upper-west-side-homeless-shelter-bill-de -blasio-20200909-r42dfw52nvfgtdz5bpwla2lddy-story.html [https://perma.cc /6NMM-5APT]. 


\section{Risk Management AND Alternate USAGE}

As hotels explore various sources of alternate income, owners and operators must carefully consider the risks associated with non-traditional property usage. ${ }^{110}$ Special considerations could include liability exposure, insurance coverage limitations, negotiating contract terms, zoning ordinance limitations, and even community resistance to housing homeless populations. ${ }^{11}$ Owners would be wise to seek legal counsel and together carefully weigh all associated risks when considering new income sources and negotiating alternate use contracts. ${ }^{112}$ Mitigating risk exposure is critical to realizing financial benefit for the business while exploring non-traditional income sources. ${ }^{113}$

\section{A. Liability Protection}

As the first wave of hotels began to implement non-traditional usages during the crisis, industry leaders immediately focused their attention on risk management and decreasing hotel operators' exposure to liability. ${ }^{114}$ Hotel trade associations joined forces to collectively bring their concerns to Congress's attention in Coronavirus Aid, Relief, and Economic Security ("CARES") Act discussions. ${ }^{115}$ The group first addressed the industry's essential business designation by the Cybersecurity and Infrastructure Security Agency. ${ }^{116}$ This designation allowed hotels to provide lodging to first responders and health care workers working on the front lines battling the pandemic. ${ }^{117} \mathrm{Sec}-$ ond, the group addressed hotel usage by state and local governments in providing alternative health care sites and housing vulnerable

110. COVID-19: Addressing the Risks of Nontraditional Hotel Use, MARSH MCLENNAN, https://www.marsh.com/us/insights/research/covid-19-addressingrisks-of-nontraditional-hotel-use.html [http://perma.cc/UB66-G69Y].

111. Id.; See Chris Glorioso, NYC Residents Want Homeless Moved Out of Hotels,

Fear Their Safety is Compromised, NBC NY (Aug. 7, 2020, 9:23 AM), https:/ /www.nbcnewyork.com/news/local/nyc-residents-want-homeless-moved-out-of-

hotels-fear-their-safety-is-compromised/2556242/ [http://perma.cc/2KXD-KXYK].

112. COVID-19: Addressing the Risks of Nontraditional Hotel Use, MARSH MCLENNAN, https://www.marsh.com/us/insights/research/covid-19-addressingrisks-of-nontraditional-hotel-use.html [http://perma.cc/UB66-G69Y].

113. Id.

114. Hotel Industry Letter to Congress, AM. Hotel \& LodGING Ass'N (May 20, 2020), https://www.ahla.com/sites/default/files/updated_hotel_industry_letter_to congress_covid_priorities_final_0.pdf [http://perma.cc/J342-C $\overline{4 X F}]$.

115. Id.

116. Id.

117. Id. 
populations. ${ }^{118}$ These non-traditional usages provided much needed resources to the population but simultaneously exposed the hotels to increased COVID-19 risks. ${ }^{119}$ Leaders recognized that " $[\mathrm{t}]$ hese operations, and as hotels look to return to normal business operations, present difficult legal questions with respect to potential COVID-19 exposure." 120 Concerned with these associated risks, hotel industry leaders urged Congress to consider that "[a]ny hotel that reopens and follows proper public health guidance to protect employees and guests should be afforded a limited safe harbor from exposure liability related to COVID-19." 121

Various states enacted legislation to provide liability protection to businesses for coronavirus-related claims, ${ }^{122}$ and the AHLA introduced an industry-wide safety standard protocol, "Stay Safe," providing additional safeguards. ${ }^{123}$ AHLA developed Stay Safe to provide a standard of best practices for hotel owners. ${ }^{124}$ Enacted liability limits and issued safety standards are just the beginning of liability protections. ${ }^{125}$ Whether open for traditional patronage or contracted for a form of alternate usage, prudent hotel owners should be fully aware of all required safety protocols ${ }^{126}$ - likely to remain in effect for an extended timeframe beyond the declared emergency-and develop internal policies and procedures to ensure facility-wide compliance and consistency. ${ }^{127}$ Hoteliers in alternate use situations should be clear on the responsibilities of each of the involved parties to an occupancy agreement and develop a detailed action plan for the hotel's

118. $I d$.

119. Id.

120. $I d$.

121. Id.

122. Seth Pierce Johnson \& Laura G. Hester, An Invisible Shield: States Begin Enacting COVID-19 Liability Protections, THE NAT'L L. Rev. (July 20, 2020), https: //www.natlawreview.com/article/invisible-shield-states-begin-enacting-covid-19liability-protections [http://perma.cc/DV95-P75H].

123. See Safe Stay: Enhanced Industry-Wide Hotel Cleaning Guidelines in Response to COVID-19, AM. HOTEL \& LODGING Ass'N, at 6 (Oct. 28, 2020), https:/ /www.ahla.com/sites/default/files/safestayguidelinesv4_102820_1.pdf [http:/ /perma.cc/9WTD-BMU6] [hereinafter Safe Stay].

124. Id. at 4.

125. Am. Hotel \& Lodging Ass'n, Hotel Industry Pandemic Liability Protection 1-2, https://www.ahla.com/sites/default/files/covid19_hotel_liability_exposure cozen 0.pdf [https://perma.cc/Q2D2-JZJW].

126. See Safe Stay, supra note 123, at 6.

127. S. Christopher Collier \& Bryan M. Grantham, Protecting Your Hotel From Liability During COVID-19, HAWKINS PARnell (May 15, 2020), https:/ /www.hpylaw.com/publications/protecting-your-hotel-from-liability-during-covid19/ [https://perma.cc/V9X9-ZGNA]. 
responsibilities. ${ }^{128}$ Additionally, thorough documentation of the hotel's compliance with policies and procedures in all circumstances could serve as a valuable reference for defense of potential liability claims. ${ }^{129}$ Mitigating liability exposure is important for all properties conducting traditional operations but becomes a critical issue when contracting for non-traditional usage. ${ }^{130}$

\section{B. Commercial Insurance Coverage}

Owners and counsel should also be aware of potential coverage exclusions contained within commercial insurance policies. ${ }^{131}$ Owners should examine policy requirements, particularly for change of use provisions, which would require informing insurance companies of alternate uses outside the scope of traditional travel patronage. ${ }^{132}$ To ensure sufficient coverage for both individual occurrences and aggregate amounts, owners should review liability coverages for injury or damages, including risks of protecting from virus exposure while on the premises. ${ }^{133}$ Insurance providers could potentially face additional underwriting concerns with property usages differing from those considered at the time of policy placement. ${ }^{134}$ Insurance providers may

128. Hotel Industry Perspectives for COVID-19, AON, at 1-4 (Mar. 22, 2020), https://www.aon.com/getmedia/8c637270-a5f2-4e03-8982-1f4baf236a86/Aon-Hotel-Industry-Perspectives-For-COVID-19-Non-Traditional-Use-2020-03-22.aspx [https://perma.cc/76GE-Y2WQ] (discussing liability for alternate usages that might involve additional equipment brought onsite) [hereinafter Hotel Industry Perspectives].

129. See Judy R. Nemsick \& Valerie E. Brown, Businesses Are Reopening: Are You Safe From Claims?, Holland \& KNIGHT (May 11, 2020), https:/ /www.hklaw.com/en/insights/publications/2020/05/businesses-are-reopening-areyou-safe-from-claims [https://perma.cc/C34L-N95R]; see also Comprehensive Generic Checklist for Hotels and Resorts, SAFETYRISK, https://safetyrisk.net/wp-content/uploads/2015/08/Comprehensive-Hotel-Resort-Risk-Management-Checklist.pdf [https://perma.cc/85JQ-SUGC].

130. Hotel Industry Perspectives, supra note 128, at 1-3.

131. COVID-19: Addressing the Risks of Nontraditional Hotel Use, MARSH MCLENNAN, https://www.marsh.com/us/insights/research/covid-19-addressingrisks-of-nontraditional-hotel-use.html [http://perma.cc/UB66-G69Y].

132. Id.; S. Christopher Collier \& Bryan M. Grantham, Protecting Your Hotel From Liability During COVID-19, HAWKINS PARNELl (May 15, 2020), https:/ /www.hpylaw.com/publications/protecting-your-hotel-from-liability-during-covid19/ [https://perma.cc/V9X9-ZGNA].

133. See Neilson, Hotel Insurance: Liability, Programs, Costs, \& More, PROGRAM Bus. (May 2, 2021), https://www.programbusiness.com/blog/hotel-insurance-liability-programs-costs-more [https://perma.cc/KJ7P-NUJ5].

134. COVID-19: Addressing the Risks of Nontraditional Hotel Use, MARSH MCLENNAN, https://www.marsh.com/us/insights/research/covid-19-addressingrisks-of-nontraditional-hotel-use.html [http://perma.cc/UB66-G69Y]. 
require supplemental underwriting information, which could include copies of the contracts, insurance certificates, detailed scope of use, property details, exposure estimates, and Centers for Disease Control and Prevention ("CDC") compliance protocols. ${ }^{135}$

\section{Contract Negotiations}

Risk management professionals acknowledge there may not be much room for negotiation in government contracts; however, due diligence would require in-depth review of all contract provisions. ${ }^{136}$ To avoid misunderstandings and disagreements, contract terms should clearly set forth the responsibilities of each party. ${ }^{137}$ " $[\mathrm{H}]$ otel owners and their counsel should seek to secure strong indemnification and insurance requirements, including additional insured status, waivers of subrogation, and primary and noncontributory wording." ${ }^{138}$ In certain cases, owners may encounter insurance liability caps that may be limited to a maximum of $\$ 5$ million. ${ }^{139}$

\section{Indemnification}

Indemnification clauses, also referred to as hold harmless clauses, are a common contract provision, applicable in various types of contracts. ${ }^{140}$ These provisions are a negotiated method of allocating losses that arise from the contractual arrangement with one party agreeing to indemnify the other by holding the other party harmless for the specified loss or injury. ${ }^{141}$ Negotiation of an indemnification clause would allow the hotel to at least partially shift liability onto the other contracting party, whether that be a government entity or a private party. ${ }^{142}$

The true purpose of contractual indemnification is to provide one party (such as a buyer) with a clear contractual remedy

135. Id.

136. Id.

137. Hotel Industry Perspectives, supra note 128, at 3.

138. COVID-19: Addressing the Risks of Nontraditional Hotel Use, MARSH MCLENNAN, https://www.marsh.com/us/insights/research/covid-19-addressingrisks-of-nontraditional-hotel-use.html [http://perma.cc/UB66-G69Y].

139. Id.

140. D. Hull Youngblood, Jr. \& Peter N. Flocos, Drafting and Enforcing Complex Indemnification Provisions, 56 PRAC. L. 21, 28 (Aug. 2010).

141. Id. at 22.

142. COVID-19: Addressing the Risks of Nontraditional Hotel Use, MARSH MCLENNAN, https://www.marsh.com/us/insights/research/covid-19-addressingrisks-of-nontraditional-hotel-use.html [http://perma.cc/UB66-G69Y]. 
for recovering post-closing monetary damages arising from: [b]reach of a covenant; [b]reach of representation or warranty; [c]laims by third parties against the indemnitee; or $[0]$ ther claims provided in the relevant agreement. ${ }^{143}$

Owners and counsel should carefully draft and negotiate indemnification terms that are specific to the unique circumstances, considering that the non-traditional usage of the property might present liability concerns beyond the normal scope of property use. ${ }^{144}$ These contracts might require more specialized terms addressing the unique situation, such as housing individuals for longer periods of time than traditional patrons, or a shift in purpose, such as overflow facilities for universities. ${ }^{145}$ With a custom approach in drafting provisions, owners could potentially limit liability occurrences by defining key terms such as claims, instances, parties, and damages. ${ }^{146}$ Additionally, the opportunity would exist to negotiate terms within the clause to include expenses such as attorney's fees and lost income related to claims. ${ }^{147}$

\section{Changes Clause}

Hoteliers undertaking the negotiation of contracts need to be conscious of unique characteristics of government contracting, specifically the changes clause, which is required in federal contracts and potentially present in other government contracts as well. ${ }^{148}$ "Unlike parties to purely commercial contracts, the Government has a nearly unlimited right to change a contract, even after performance starts." 149 The clause provides the government contracting officer with "the unilateral power to change the contract in a variety of situations" and is "free to make any desired changes that are "within the general scope of the contract." 150 Such contract terms require the contracting party to continue performance according to the terms and conditions of the contract, including all changes implemented by the contracting

143. Youngblood \& Flocos, supra note 140, at 21-22.

144. Id. at 22 ("Each fact situation should be analyzed to determine the best method of risk allocation.").

145. Id.; see also COVID-19: Addressing the Risks of Nontraditional Hotel Use, MARSH MCLENNAN, https://www.marsh.com/us/insights/research/covid-19-addressing-risks-of-nontraditional-hotel-use.html [http://perma.cc/UB66-G69Y].

146. Youngblood \& Flocos, supra note 140, at 27.

147. Id. at 27-29.

148. Kathleen E. Karelis \& David B. Robbins, Government Contracting After a National Disaster, 05-11 BRIEFING PAPERS 1, 9 (October 2005).

149. Id.

150. Id. at 10 . 
officer. ${ }^{151}$ Government contracting can be a beneficial option in declared emergency situations, potentially providing alternate usage income for hotels when traditional occupancy is interrupted. ${ }^{152}$ However, owners need to be cautious when reviewing contract terms and be certain the benefits will outweigh potential risks that accompany contracts containing the negotiated ability to be freely altered. ${ }^{153}$

\section{Sovereign Immunity}

Another key issue for hotel owners to weigh as they consider government contracts for alternative usage is the concept of liability in relation to qualified immunity. ${ }^{154}$ Sovereign immunity is the "state's immunity from being sued in federal court by the state's own citizens." 155 The sovereign immunity doctrine originated from the need to shield the federal government from liability claims. ${ }^{156}$ Qualified immunity extended the shield of protection, providing "immunity from civil liability for a public official who is performing a discretionary function, as long as the conduct does not violate clearly established constitutional or statutory rights." 157 This concept expanded as the government's needs expanded and came to also shield contractors acting on behalf of the federal government. ${ }^{158}$ The Supreme Court in Yearsley v. W.A. Ross Construction, Co. extended immunity protection when "it is clear that if this authority to carry out the project was validly conferred, that is, if what was done was within the constitutional power of Congress, there is no liability on the part of the contractor for executing its will." 159 This extension of governmental immunity was further examined in Campbell-Ewald Co. v. Gomez in 2016, where the Court held that federal contractors do not share in the same unqualified immunity as the federal government, but rather a

151. Id. at $9-10$.

152. Id. at 17.

153. Id.

154. See COVID-19: Addressing the Risks of Nontraditional Hotel Use, MARSH MCLENNAN, https://www.marsh.com/us/insights/research/covid-19-addressingrisks-of-nontraditional-hotel-use.html [http://perma.cc/UB66-G69Y].

155. Sovereign immunity, BLACK'S LAW DICTIONARY (11 th ed. 2019).

156. Victoria Eatherton, Is Derivative Sovereign Immunity Jurisdictional? An Analysis and Resolution of the Circuit Split, 47 PUB. CONT. L.J. 605, 608-09 (2018).

157. Qualified immunity, BLACK's LAW DictionARY (11th ed. 2019).

158. Eatherton, supra note 156, at 606.

159. 309 U.S. 18, 20-21 (1940) ("Where an agent or officer of the Government purporting to act on its behalf has been held to be liable for his conduct causing injury to another, the ground of liability has been found to be either that he exceeded his authority or that it was not validly conferred."). 
qualified immunity that stems from the contracted relationship so long as the work is within the scope of the contract. ${ }^{160}$

The Court distinguished cases where government agents exceeded the scope of granted authority from instances where the granted authority "was not validly conferred." 161 The Court was clear to differentiate circumstances in which the party could be liable for conduct that resulted in injury to a third party. ${ }^{162}$ Most importantly from the perspective of hotel property owners, the Gomez opinion emphasized that there was no distinction "between public servants and private individuals engaged in public service," which is the case with private businesses contracting hotel space. ${ }^{163}$

While these cases generally focus on federal government contracts, the concept of immunity for hotel owners entering into emergency contracts with state and local governments remains a bit less defined. ${ }^{164}$ Recognizing the potential deficiency, states have begun to address the issue. ${ }^{165}$ One such example is Ohio's House Bill 606, which took effect on December 16, 2020, and provides qualified immunity to businesses, organizations, and individuals against claims of COVID-19 related liabilities and excludes claims of willful or wanton conduct. ${ }^{166}$ Proactive state action to protect citizens and businesses has spread throughout the United States with at least a dozen states limiting pandemic liabilities through legislation. ${ }^{167}$ For COVID-related alternate usage, it would be imperative that hotel owners, together with

160. 577 U.S. 153, 166-67 (2016) (explaining that qualified immunity is not absolute, but limited to the "contractual undertakings," and is beneficial to reduce the potential risks for government contractors and promote the contractual relationships).

161. Id. at 167.

162. Id.

163. Id. (citing Filarsky v. Delia, 566 U.S. 377, 387 (2012) (holding that a private attorney retained by a municipal government temporarily could be shielded from liability)).

164. Philip J. Bradbury \& Ryan P. Heiden, When Can a Private Contractor Receive Governmental Immunity?, THE NAT'L L. REV. (Apr. 20, 2017), https:/ /www.natlawreview.com/article/when-can-private-contractor-receive-governmental-immunity [https://perma.cc/XD7K-XRXE].

165. Seth Pierce Johnson \& Laura G. Hester, An Invisible Shield: States Begin Enacting COVID-19 Liability Protections, THE NAT'L L. REV. (July 20, 2020), https: //www.natlawreview.com/article/invisible-shield-states-begin-enacting-covid-19-

liability-protections [http://perma.cc/DV95-P75H].

166. H.R. 606, 133d Gen. Assemb., Reg. Sess. (Ohio 2020).

167. Seth Pierce Johnson \& Laura G. Hester, An Invisible Shield: States Begin Enacting COVID-19 Liability Protections, THE NAT'L L. REV. (July 20, 2020), https: //www.natlawreview.com/article/invisible-shield-states-begin-enacting-covid-19liability-protections [http://perma.cc/DV95-P75H]. 
legal counsel, examine contracts with specific attention to the details regarding potential qualified immunity. ${ }^{168}$ Additionally, owners would need to research appropriate state liability shield legislation to determine just what protections their jurisdiction has provided. ${ }^{169}$ States will likely limit the distinctive applications of these protections and include a time restriction component. ${ }^{170}$

Although these examples deal specifically with COVID-19 related liabilities, the issue of qualified immunity is applicable in all government contracts, including those for alternate usage. ${ }^{171}$ Due diligence requires thorough contract examination to determine if the hotel has any amount of qualified immunity in the case of liability claims related to alternate usage. ${ }^{172}$ Owners who are willing to be creative in seeking non-traditional income sources would need to ensure that their business or property is a covered party under the contract language. ${ }^{173}$ These issues would provide a starting point for an in-depth review of contract provisions in effort to avoid unnecessary liability exposure.

\section{Reduced Hotel Property Values}

An additional cause of concern for hotel owners is the potential reduction in property values during the economic downswing and the possible long-term effects of the reduction. ${ }^{174}$ Even though the hospitality market routinely experiences normal fluctuations, a downturn in the economy brings a mirroring downturn in hotel valuations. ${ }^{175} \mathrm{In}$ general, hotel properties can suffer from reduced valuation during a recession simply because the property is not able to produce normal income levels. ${ }^{176}$ Valuation of a hotel property is traditionally based

168. See COVID-19: Addressing the Risks of Nontraditional Hotel Use, MARSH MCLENNAN, https://www.marsh.com/us/insights/research/covid-19-addressingrisks-of-nontraditional-hotel-use.html [http://perma.cc/UB66-G69Y].

169. See Chris Marr, State Prolong COVID-19 Liability Shields as Pandemic Persists, BLOOMBERG LAW (Apr. 20, 2021, 12:38 PM), https://news.bloomberglaw.com /daily-labor-report/states-prolong-covid-19-liability-shields-as-pandemic-persists

[https://perma.cc/C467-BVJS].

170. See id.

171. Eatherton, supra note 156, at 607-08.

172. COVID-19: Addressing the Risks of Nontraditional Hotel Use, MARSH MCLENNAN, https://www.marsh.com/us/insights/research/covid-19-addressingrisks-of-nontraditional-hotel-use.html [http://perma.cc/UB66-G69Y].

173. Id.

174. AnNe R. Lloyd-Jones et Al., The ImPaCt of COVID-19 ON Hotel VALUES 7 (2020), https://www.hvs.com/article/8745-the-impact-of-covid-19-onhotel-values [http://perma.cc/Q4ER-WLYR].

175. Id. at 4 .

176. Id. at 6 . 
on calculations of room rates and transaction volume and reflects fluctuations in the market. ${ }^{177}$ This potential reduction is an important consideration for owners contemplating the sale of hotel properties. ${ }^{178}$ Although property liquidation may be the only viable financial decision, there is potential for significant loss due to a temporary reduction in valuation. ${ }^{179}$ The current market situation is unique because it reflects the global reach of the pandemic rather than a contained regional market fluctuation and, therefore, would affect valuation industrywide. ${ }^{180}$ Although acknowledging the uncertain timeframe for travel to return to normal and increase the demand for hotel services, hospitality industry professionals predict that when the market does return to normal operations, there should not be a permanent reduction in property values. ${ }^{181}$

\section{Community Resistance}

The sheltering of homeless populations in vacant hotels has caused some community resistance, which is often labeled as not in my backyard ("NIMBY") opposition. ${ }^{182}$ Areas such as New York City's Upper West Side and Laguna Hills, California, have experienced pushback from local residents that claim threats to the safety of the community. ${ }^{183}$ Conflict arose in Orange County, California when the county chose a 138-bed hotel located next to a senior community as temporary housing for the homeless. ${ }^{184}$ Laguna Hills filed suit against Orange County claiming that the county violated existing Covenants, Conditions, Restrictions, and Reservations of Easements ("CC\&Rs") by entering a temporary housing agreement with a local hotel. ${ }^{185}$ The city claimed that existing CC\&Rs prevented the agreement because the "attempt to use the Hotel to shelter and treat COVID19 patients constitutes a change of use of the Hotel without the

177. Id. at 2 .

178. See id.

179. See id. at 10.

180. See id. at 2.

181. Id. at 10 .

182. Roy et al., supra note 14, at 22.

183. Id. at $22,44$.

184. Coronavirus: Here's How Putting California's Homeless in Hotels Actually Works, MERCURY News (Apr. 11, 2020, 1:42 PM, last updated Sept. 20, 2020, 4:14 PM), https://www.mercurynews.com/2020/04/11/coronavirus-heres-how-puttingcalifornias-homeless-in-hotels-actually-works/ [http://perma.cc/CSZ6-QLMH] .

185. See Complaint at 1, City of Laguna Hills v. Elite Hosp., Inc, No. 30-202001139345-CU-MC-CJC, https://lagunahillsca.gov/DocumentCenter/View/5041 /Copy-of-Lawsuit?bidld= [http://perma.cc/WHK9-68SF $]$. 
required prior approval by the City or [the community development committee]." 186 The suit additionally claimed the "attempt to use the Hotel to shelter and treat COVID-19 patients constitutes a significant health and safety risk and a nuisance within the meaning of, and in violation of ... the CC\&Rs." 187 Ultimately, the arguments for code violations failed for the plaintiffs because the pandemic emergency orders superseded the applicable zoning ordinances. ${ }^{188}$ Even though emergency orders should supersede zoning ordinances in most situations, community NIMBY opposition and the filing of lawsuits opposing the shelters could continue to cause conflict as local residents counteract the change in use. ${ }^{189}$ The NIMBY conflicts could result in contract negotiation delays and excess legal expenditures - obstacles that can prolong the alternative income supplementation. ${ }^{190}$

Permanent conversion of hotel property to homeless shelters could potentially face the same type of opposition based on claims of zoning violations for change of use or through zoning board resistance. In New York, a neighborhood organization attempted to prevent the conversion of a nine-story former hotel property to an employment shelter for homeless men. ${ }^{191}$ The court rejected the argument that all shelters are transient in nature and, instead, examined the differences in housing classifications under the applicable building code and the effects of those classifications as they relate to zoning challenges. ${ }^{192}$ The occupancy groups are separated based on length of stay with the line of distinction centering around a 30-day time period. ${ }^{193}$ A facility zoned for transient usage of less than 30 days would then be more likely to remain in conformance when the proposed alternate usage follows similar time restrictions. Upon consideration of permanent conversion, prudent practice would be to research zoning ordinances pertaining to the specific property location to determine local

186. Id. at 10 .

187. Id.

188. Roy et al., supra note 14, at 22.

189. Id. at $15-16$.

190. Id.

191. See W. 58th St. Coal., Inc. v. City of N.Y., 130 N.Y.S.3d 436 (N.Y. App. Div. 2020), aff'd as modified, W. 58th St. Coal., Inc. v. City of N.Y., No. 33 slip op. 03346 (N.Y. 2021).

192. Id. at 443-44 (explaining that the property had been zoned for non-transient single-room occupancy, the same classification as the proposed employment shelter providing non-transient, permanent housing for men, which permitted the shelter under the existing ordinance).

193. Id. 
occupancy classifications and whether the proposed usage would create a potential zoning conflict.

\section{PeRmanent Hotel Property CONVERSiON}

While sheltering the homeless population has been an immediate concern during the COVID-19 pandemic in cities with the highest levels of homelessness, the issue has received increased exposure and highlighted the need for a solution beyond the pandemic. ${ }^{194}$ In some cities where property owners have been emergency contracting with government officials to provide vacant rooms for homeless occupancy, advocates are pushing for cities to take a more permanent approach. ${ }^{195}$

\section{A. Selling Hotel Properties: Investor Purchase Versus Government Purchase}

As the pandemic increased in magnitude and duration, discussions began to surface in various locations of possible hotel purchase option negotiations to convert to permanent shelters. ${ }^{196}$ Early in the contracting stages, California officials began to explore the option of converting these temporary hotel contracts into purchase options for permanent housing for the homeless. ${ }^{197}$ Recognizing the dire financial circumstances most of these hotels faced and the ease of conversion from temporary to permanent accommodations, officials expressed interest in pursuing the option. ${ }^{198}$

In spite of optimism for the travel industry to return to preCOVID conditions, the fact remains that across the country there are

194. Scott Rodd, California Leasing Hotels for Homeless People During Coronavirus Crisis - and After Could Make Them Permanent Housing, CAPRADIO (Mar. 24, 2020), https://www.capradio.org/articles/2020/03/24/california-leasing-hotelsfor-homeless-people-during-coronavirus-crisis-and-after-could-make-them-permanent-housing/ [http://perma.cc/HF2X-MVCX].

195. Id.

196. See Shiela Pozon et al., Hotel and Office Conversions - an Update, KRAMER LEVIN (June 14, 2021), https://www.kramerlevin.com/en/perspectives-search/hoteland-office-conversions-an-update.html?utm_source $=$ Mondaq\&utm_medium $=$ syndication\&utm_campaign=LinkedIn-integration [https://perma.cc/A $\overline{\mathrm{K}} 6 \mathrm{~J}-\mathrm{MKSL}]$.

197. Scott Rodd, California Leasing Hotels for Homeless People During Coronavirus Crisis - and After Could Make Them Permanent Housing, CAPRADIO (Mar. 24, 2020), https://www.capradio.org/articles/2020/03/24/california-leasing-hotelsfor-homeless-people-during-coronavirus-crisis-and-after-could-make-them-permanent-housing/ [http://perma.cc/HF2X-MVCX].

198. Id. 
numerous hotel properties that remain in distress. ${ }^{199}$ With the prolonged effects of the pandemic and predictions that occupancy will likely not to return to pre-COVID rates for another two to three years, ${ }^{200}$ owners may want to consider liquidation to salvage any remaining equity. Hoteliers in dire circumstances with vacant properties and those with temporary alternate use contracts alike may be easy targets for investors looking to take advantage of the distressed businesses and acquire the properties. ${ }^{201}$ As the industry anticipates a spike in investment purchases, advocates are pushing for local governments to step in and negotiate purchases of these hotel properties to circumvent the potential of large-scale investor purchases. ${ }^{202}$ Advocates, fearing a repeat of the economic crisis of the Great Recession and worry that vulnerable communities "will become hot spots of predatory speculation" for "public investment projects that generate displacement," urge governments to consider that "public acquisition of housing, specifically the acquisition of hotels and motels, can be an important cornerstone of neighborhood stabilization." 203 This public policy approach would encourage government purchase of these struggling hotel properties for conversion to homeless facilities in an effort not only to preserve the neighborhoods but to provide housing for families experiencing homelessness by providing available facilities within their existing communities. ${ }^{204}$ Proponents of this neighborhood stabilization suggest government acquisition as a community protection mechanism with commandeering as a possible alternative. ${ }^{205}$

\section{B. Commandeering and Permanent Conversion}

Programs designed to house the homeless during the pandemic have exposed the ongoing homeless crisis to increased public attention. ${ }^{206}$ As hotels were contracting with the government for temporary

199. Diana Olick, Want to Own an Apartment Building? Buy a Distressed Hotel for Pennies on the Dollar, CNBC (Feb. 4, 2021, 8:56 AM), https://www.cnbc.com /2021/02/04/want-to-own-an-apartment-building-buy-a-distressed-hotelcheap.html [https://perma.cc/6MDD-PZKL].

200. Hotel Industry 2021, supra note 15, at 9.

201. Diana Olick, Want to Own an Apartment Building? Buy a Distressed Hotel for Pennies on the Dollar, CNBC (Feb. 4, 2021, 8:56 AM), https://www.cnbc.com /2021/02/04/want-to-own-an-apartment-building-buy-a-distressed-hotelcheap.html [https://perma.cc/6MDD-PZKL].

202. See Roy et al., supra note 14, at 23.

203. Id.

204. Id.

205. Id. at $17,22-23$.

206. Id. at $5,10-11$. 
housing, advocates took the opportunity to champion the need for more permanent solutions for housing alternatives. ${ }^{207}$ " $[\mathrm{H}]$ ousing justice movements and community organizations, such as the statewide No Vacancy! campaign, have issued a loud and sustained call for the commandeering of hotel and motel rooms, focusing scrutiny on the luxury hotels in downtown Los Angeles that have received large public subsidies in the process of development." 208 A San Francisco emergency ordinance, adopted April 14, 2020, granted authority to the mayor to procure over 8,000 rooms for temporary housing and "despite exhausting reasonable options for securing these rooms through agreements, the [m]ayor is urged to acquire any additional private rooms needed . . . through prompt exercise of the [m]ayor's authority to commandeer property under Charter Section 3.100(14)." ${ }^{209}$ The San Francisco City Attorney issued a memo to city officials explaining that commandeering hotel property was an option available under the authority of the city. ${ }^{210}$ The memo emphasized that although the city has the authority to commandeer property, to act on that power required "adequate justification for its acts, and must narrowly tailor those acts to the particular circumstances." 211

To commandeer hotel property for conversion to permanent homeless housing would require the city to "compensate the owner for the "fair value' of the property" and "may, but is not required to, set forth the amount of payment to be made for the property" at the time of the commandeer order. ${ }^{212}$ If hotel property owners were to find themselves the subject of a commandeering order, they would need to urgently seek legal counsel to protect their interests. Negotiating fair value would be a primary concern. The San Francisco memo addressed the absence of specific procedures for determining the fair market value of the subject property, ${ }^{213}$ which leaves the process vulnerable to potential inconsistencies. Legal counsel should cautiously

207. Id. at 18 .

208. Id. at 17.

209. S.F., Cal., Ordinance 69-20, Emergency Ordinance: Limiting COVID-19 Impacts Through Safe Shelter Options, at 7 (Apr. 14, 2020), https://sfbos.org/sites /default/files/o0069-20.pdf [http://perma.cc/9P7Z-BE8D].

210. See Memorandum from Off. of the City Att'y to Mayor and Bd. of Supervisors 2 (Apr. 13, 2020), https://www.sfcityattorney.org/wp-content/uploads/2020/04 /City-Power-to-Commandeer-Private-Property-for-COVID-19-EmergencyPurposes.pdf [http://perma.cc/5ZNT-D3BB].

211. Id. at 4 .

212. Id. at 2 .

213. Id. at 3 . 
examine such orders and advocate for fair treatment on behalf of hotel property owner clients.

\section{CONCLUSION}

The immediate pandemic crisis has been especially harsh for the hospitality industry. The existence of federal disaster programs to provide for alternate income has been a form of financial life support for struggling hotel properties. The challenge for hotel owners now is to evaluate their traditional business models and creatively plan for the future. The global pandemic will eventually draw to a close, but the effects will likely linger for several years and could potentially have permanent effects. Creative-thinking hotel owners could apply the alternate usage concepts from the pandemic into a long-term contingency plan for severe market fluctuations by seeking advance planning contracts and non-traditional usage contracts. Additionally, the most distressed properties could very well find themselves in a prime position to negotiate property sales contracts with local government entities and corporate investors. The hospitality industry has historically proven its resiliency through economic fluctuations and will undoubtedly adapt by embracing non-traditional income sources to survive the current pandemic and to prepare for future financial hardships. 